\title{
IMMUNOHISTOCHEMICAL ALTERATIONS OF DYSTROPHIN IN CONGENITAL MUSCULAR DYSTROPHY
}

\author{
LINEU CESAR WERNECK*, EDUARDO BONILLA **
}

SUMMARY - The dystrophin distribution in the plasma muscle membrane using immunohystochemistry was studied in 22 children with congenital muscular dystrophy. The dystrophin was detected by immunofluorescence in muscle biopsy through a polyclonal antibody. All the cases had patchy interruptions of the fluorescence in the plasma membrane. A large patchy interruption of the sarcolemma was found in 17 cases, small interruption in 12 , and a combination of large and small patchy discontinuity in 7 . Small gaps around the fiber like a rosary were found in 15 cases. The frequency of these abnormalities ranged cases from: all fibers in 5 cases, frequent in 8 , occasional in 5 , and rare in 4 . Five cases had total absence of immunofluorescence. These results suggest that the dystrophin expression is abnormal in this group of children and that this type of abnormalities can not be differentiated from early Becker muscular dystrophy nor childhood autosomal recessive muscular dystrophy through immunohystochemistry alone.

KEY WORDS: congenital muscular dystrophy, dystrophin, congenital myopathies.

\section{Alteraçōes imuno-histoquímicas da distrofina na distrofia muscular congênita}

RESUMO - Foi estudada a distribuição da distrofina na membrana plasmática das fibras musculares em 22 crianças com distrofia muscular congênita, através de técnicas de imuno-histoquímica. A distrofina foi identificada nas biópsias musculares processadas a fresco, por técnicas de imunofluorescência utilizando anticorpos policlonais. Todos os casos tinham interrupçōes da imunofluorescência na membrana plasmática. Em 17 elas eram grandes, em 12 eram pequenas e em 7 eram de ambos os tipos. Fibras com interrup̧ões pequenas e constantes, como um rosário, foram vistas em 15 casos. Essas anormalidades estavam presentes em todas as fibras em 5 casos, eram frequentes em 8, ocasionais em 5 e raras em 4 . Cinco casos mostraram fibras sem distrofina. Esses dados sugerem que a expressāo da distrofina é anormal nesse grupo de crianças. Essas anormalidades podem também ser encontradas em casos precoces de distrofia muscular de Becker e distrofia autossômica recessiva da infância. Portanto, isoladamente a imuno-histoquímica não permite a diferenciação.

PALAVRAS-CHAVE: distrofia muscular congênita, distrofina, miopatias congênitas.

The characterization of dystrophin as a product of the Duchenne muscular dystrophy locus led to the demonstration of their localization in the normal sarcolemma of muscle cells, and cerebral and spinal neurons ${ }^{599.10}$. The dystrophin is deficient in most fibers of Duchenne muscular dystrophy. It has an abnormal distribution in some fibers of Becker muscular dystrophy, and also in female carriers for the gene of Duchenne muscular dystrophy ${ }^{5,6,23}$. The abnormal distribution of dystrophin is very important in the diagnosis of these diseases, and further studies are necessary in other muscular dystrophies, such as the congenital muscular dystrophy ${ }^{1.2}$.

From the *Serviço de Doenças Neuromusculares do Hospital de Clinicas da Universidade Federal do Paraná, Curitiba, Brasil, and **Department of Neurology of the College of Physicians and Surgeons of Columbia University, New York, USA. Aceite:13-fevereiro-1995.

Dr. Lineu Cesar Werneck - Hospital de Clínicas, Rua General Carneiro 181, Serviço de Doenças Neuromusculares, $3^{\circ}$ andar - 80069-165 Curitiba PR - Brasil. 
In this paper, the pattern of the dystrophin distribution in 22 cases of congenital muscular dystrophies is reported.

\section{MATERIAL AND METHODS}

Twenty-two patients with congenital muscular dystrophies are studied, 13 males and 9 females. All the patients had a delay in the motor milestones with severe hypotonia and some had arthrogryposis. The mean age at the time of the biopsy was 3.54 years-old, and at the time the first symptoms were observed, mean age was 0.12 years-old. Mean creatinekinase was 10.46 times the normal value (TNV), lactic dehydrogenase was 0.77 TNV, aldolase was $2.33 \mathrm{TNV}$, oxalacetic transaminase was $0.27 \mathrm{TNV}$, and glutamic transaminase was 0.16 TNV. In 10 cases the electromyography was compatible with myopathy and in one of them mixed (neuromyopathic) patterns were found (Table 1).

All patients had a muscle biopsy studied by fresh-frozen section stained for modified Gomori trichrome, hematoxiline-eosin, oil red $O$, PAS and cresyl violet. Also all the biopsies had histochemical reactions for ATPase $\mathrm{pH} \mathrm{9.4,} 4.3$ and 4.6, NADH-tetrazolium reductase, myophosphorilase, non-specific esterase, succinic dehydrogenase, acid and alkaline phosphatase ${ }^{22}$ (Table 1). The histological diagnosis of this group was active myopathy in 2 , chronic myopathy in 6 , chronic myopathy with activity in 11 , inflammatory myopathy in 1 , and end stage chronic myopathy in 2 (Table 2). The diagnosis was suggested by histology-histochemistry in 16 cases $(72.7 \%)$.

The immunohistochemistry study for dystrophin was carried out in Curitiba at the Neuromuscular Laboratory of the Hospital de Clínicas da Universidade Federal do Paraná, having been used a four micron. thick frozen section incubated with polyclonal antibodies. These antibodies were raised in sheep against fusion proteins of amminoacids 407-815 (60 kDa) diluted 1:1000 in phosphate-buffered saline, using biotinylated anti-sheep and streptavidin-fluorescein and having been examined by a photo-microscope equipped with epiillumination 5.23 . All patients had a control section incubated with non-immune serum and cases with other diseases underwent the same procedure such as control for dystrophin stain. Previous works have demonstrated a good correlation of this immunofluorescence technique for dystrophin and immunoblot analysis in several diseases ${ }^{2}$.

Table I. Clinical and laboratory data.

\begin{tabular}{|c|c|c|c|c|c|c|c|c|c|c|}
\hline $\begin{array}{c}\text { Cuse } \\
\text { number }\end{array}$ & Sex & $\begin{array}{c}\text { Age at } \\
\text { investigation }\end{array}$ & $\begin{array}{l}\text { Age at first } \\
\text { symptom }\end{array}$ & $\begin{array}{l}\text { Vignos } \\
\text { Scale }\end{array}$ & CK & LDH & Aldolase & SGOT & SGPT & Electromyography \\
\hline 1 & $\mathrm{~F}$ & 0.08 & Birth & & 1.00 & 0.00 & 2.00 & 0.00 & 0.00 & Myopathic \\
\hline 2 & $\mathrm{~F}$ & 0.10 & Birth & & 27.00 & 3.00 & 2.00 & & & Neuromyopathic \\
\hline 3 & $\mathbf{M}$ & 0.20 & Birth & & 20.00 & 1.00 & 10.00 & 0.00 & 0.00 & \\
\hline 4 & M & 3.00 & 0.08 & & 62.00 & 5.85 & 19.32 & & & \\
\hline 5 & $\mathrm{~F}$ & 0.25 & 0.08 & & 12.57 & 0.30 & 3.51 & 0.00 & 0.09 & \\
\hline 6 & $\mathrm{~F}$ & 0.30 & Birth & & 13.00 & 1.00 & & & & \\
\hline 7 & $\mathrm{~F}$ & 0.70 & 0.20 & & 1.00 & 0.00 & 0.00 & & & \\
\hline 8 & M & 0.80 & Birth & & 10.00 & 0.00 & 3.00 & 0.00 & 0.00 & \\
\hline 9 & M & 0.87 & Birth & & 31.60 & 0.69 & 0.00 & 3.66 & 2.50 & Myopathic \\
\hline 10 & $\mathrm{~F}$ & 0.90 & Birth & & 11.00 & 1.00 & & & & Myopathic \\
\hline 11 & $\mathbf{M}$ & 1.00 & Birth & & 3.24 & 0.00 & 0.00 & 0.67 & 0.00 & Myopathic \\
\hline 12 & $\mathbf{M}$ & 1.10 & 0.50 & & 5.00 & 0.00 & 2.00 & 0.00 & 0.00 & Myopathic \\
\hline $13^{*}$ & $\mathbf{M}$ & 2.00 & 0.30 & & 5.00 & 2.00 & 3.00 & 0.00 & 0.00 & Myopathic \\
\hline 14 & $\mathbf{M}$ & 3.25 & Birth & 7 & 7.05 & 0.26 & 0.93 & & & Myopathic \\
\hline 15 & $\mathrm{~F}$ & 3.25 & 1.32 & 3 & 1.00 & 0.00 & 0.00 & 0.00 & 0.00 & \\
\hline 16 & $\mathbf{M}$ & 3.30 & Birth & & & 0.00 & 0.00 & 0.00 & 0.00 & \\
\hline 17 & $\mathbf{M}$ & 7.00 & Birth & 2 & 0.00 & 0.00 & 0.00 & 0.00 & 0.00 & Myopathic \\
\hline 18 & $\mathbf{M}$ & 7.00 & Birth & 10 & 2.00 & 1.00 & 0.00 & 0.00 & 0.00 & \\
\hline 19 & $\mathrm{~F}$ & 8.90 & 0.10 & 5 & 6.00 & 1.00 & 1.00 & 0.00 & 0.00 & Myopathic \\
\hline 20 & M & 9.00 & Birth & 8 & 0.00 & 0.00 & 0.00 & 0.00 & 0.00 & \\
\hline 21 & $\mathbf{M}$ & 11.00 & 0.08 & 7 & 0.35 & 0.00 & 0.00 & 0.00 & 0.00 & Myopathic \\
\hline 22 & $\mathrm{~F}$ & 17.00 & Birth & 3 & 0.00 & 0.00 & 0.00 & 0.00 & 0.00 & Myopathic \\
\hline
\end{tabular}

* Fukuyama congenital muscular dystrophy. M, male; F, female. Age at investigation and first symptoms in years. CK, creatinekinase; LDH, lactic dehidrogenase; SGOT, aspartate aminotransferase; SGPT, alanine aminotransferase. All enzymes are expressed in number of times increased above their normal values. 
Table 2. Histological alterations in muscle biopsy (Number of cases with abnormalities).

\begin{tabular}{|c|c|c|c|c|}
\hline \multirow{2}{*}{ Type of abnormality } & \multicolumn{4}{|c|}{ Intensity of abnormalities } \\
\hline & Absent & Discrete & Moderate & Severe \\
\hline Concective tissue proliferation & & 3 & 11 & 8 \\
\hline Proliferation of adipose tissue & 4 & 4 & 9 & 5 \\
\hline Fiber size variation & & 2 & 4 & 16 \\
\hline Large group atrophy & 20 & 1 & 了 & \\
\hline Small group atrophy & 20 & 1 & 1 & \\
\hline Small angulated fibers & 20 & 2 & & \\
\hline Small rounded atrophic fibers & & 3 & 11 & 8 \\
\hline Hypertrofic fibers & 8 & 8 & 6 & \\
\hline Internal nuclei & 7 & 7 & 5 & 3 \\
\hline Necrotic fibers & 6 & 7 & 6 & 3 \\
\hline Phagocytosis & 6 & 8 & 5 & 3 \\
\hline Basophilic fibers & 16 & 5 & 1 & \\
\hline Fiber splitting & 10 & 5 & 4 & 3 \\
\hline Snake coil fibers & 18 & 1 & 3 & \\
\hline Ring fibers & 19 & & 2 & $\mathbf{I}$ \\
\hline Endomysium inflammatory reaction & 20 & 2 & & \\
\hline Excessive inflammatory reaction & 20 & 2 & & \\
\hline Type 1 fibre predominance & 13 & 9 & & \\
\hline Type 2 fibre predominance & 21 & 1 & & \\
\hline Type 1 fibre hypertrophy & 9 & 12 & & $\mathbf{I}$ \\
\hline Type 2 fibre hypertrophy & 8 & 14 & & \\
\hline Type I fibre atrophy & & 17 & 5 & \\
\hline Type 2 fibre atrophy & 4 & 15 & 3 & \\
\hline NADH-TR small dark angulated fibres & 21 & 1 & & \\
\hline NADH-TR moth eaten fibres & 20 & 1 & & 1 \\
\hline NADH-TR whorled fibres & 12 & 5 & 5 & \\
\hline Inespecific esterase small dark angulated fibres & 19 & 3 & & \\
\hline Inespecific esterase macrophages & 17 & 5 & & \\
\hline Acid phosphatase focal increased fibres & 9 & 6 & 6 & 1 \\
\hline Acid phosphatuse positive fibres & 9 & 7 & 6 & \\
\hline Acid phosphatase endomysium inflammatory cells & 14 & 6 & 2 & \\
\hline Acid phosphatase macrophages (phagocytosis) & 9 & 5 & 8 & \\
\hline Alkaline phosphatase positive fibres & 11 & 5 & 3 & 3 \\
\hline Alkaline phosphatase endomysium cells & 13 & 7 & 2 & \\
\hline
\end{tabular}

No abnormality found in the oil red $O$, PAS, cresyl violet, succinic dehydrogenase and myophosphorylase.

\section{RESULTS}

All the 22 cases had an abnormal distribution of the immunofluorescence around the fibers (Figs 1. 2 and 3; Table 3): 17 cases had large patchy discontinuity of the fluorescence in the sarcolemma, 12 had small interruptions of the dystrophin immunofluorescence, and in 7 there was a combination of both, in the same or in different fibers (Figs 1,2,3). Fifteen cases had small gaps of fluorescence in the sarcolemma at regular intervals involving the whole fiber, like a rosary (Figs 2 , 3). This rosary appearence was absent in 7 cases (possible Becker or childhood autosomal recessive muscular dystrophy). The abnormalities were: present in all fibers in 5 cases, very frequent in 8 , occasional in 5 , and rare in 4 . Five cases had fibers with total absence of sacolemma fluorescence (Table 2).

\section{COMMENTS}

The congenital muscular dystrophies comprises a heterogeneous group of children, usually floppy babies, sometimes with arthrogryposis multiplex. They present a delay in the motor development, hypotonia, decreased muscle strength, progressive muscle atrophy and severe 
Table 3. Types of abnormalities in the dystrophin immunefluorescence.

\begin{tabular}{|c|c|c|c|c|c|c|c|c|}
\hline \multirow{2}{*}{$\begin{array}{c}\text { Case } \\
\text { Number }\end{array}$} & \multicolumn{3}{|c|}{ Discontinuity } & \multicolumn{4}{|c|}{ Frequency of fibers affected } & \multirow{2}{*}{$\begin{array}{c}\text { Fibers } \\
\text { without } \\
\text { dystrophin }\end{array}$} \\
\hline & Large & Small & Rosary & All & Frequent & Occasional & Rare & \\
\hline 1 & + & + & + & & + & & & \\
\hline 2 & + & & + & + & & & & + \\
\hline 3 & + & & + & + & & & & \\
\hline 4 & + & & + & + & & & & + \\
\hline 5 & + & + & + & + & & & & \\
\hline 6 & + & & + & + & & & & + \\
\hline 7 & & + & + & & & & + & \\
\hline 8 & + & & + & & + & & & \\
\hline 9 & + & + & + & & & + & & \\
\hline 10 & + & + & + & & + & & & \\
\hline 11 & & + & & & & + & & \\
\hline 12 & + & & & & & + & & \\
\hline 13 & + & & + & & + & & & \\
\hline 14 & + & + & + & & + & & & + \\
\hline 15 & + & + & + & & + & & & \\
\hline 16 & + & & + & & + & & & \\
\hline 17 & + & + & & & & + & & \\
\hline 18 & & + & & & & + & & \\
\hline 19 & + & & + & & + & & & + \\
\hline 20 & & + & & & & & + & \\
\hline 21 & & + & & & & & + & \\
\hline 22 & + & & & & & & + & \\
\hline Total & 17 & 12 & 15 & 5 & 8 & 5 & 4 & 5 \\
\hline
\end{tabular}

+ Present.

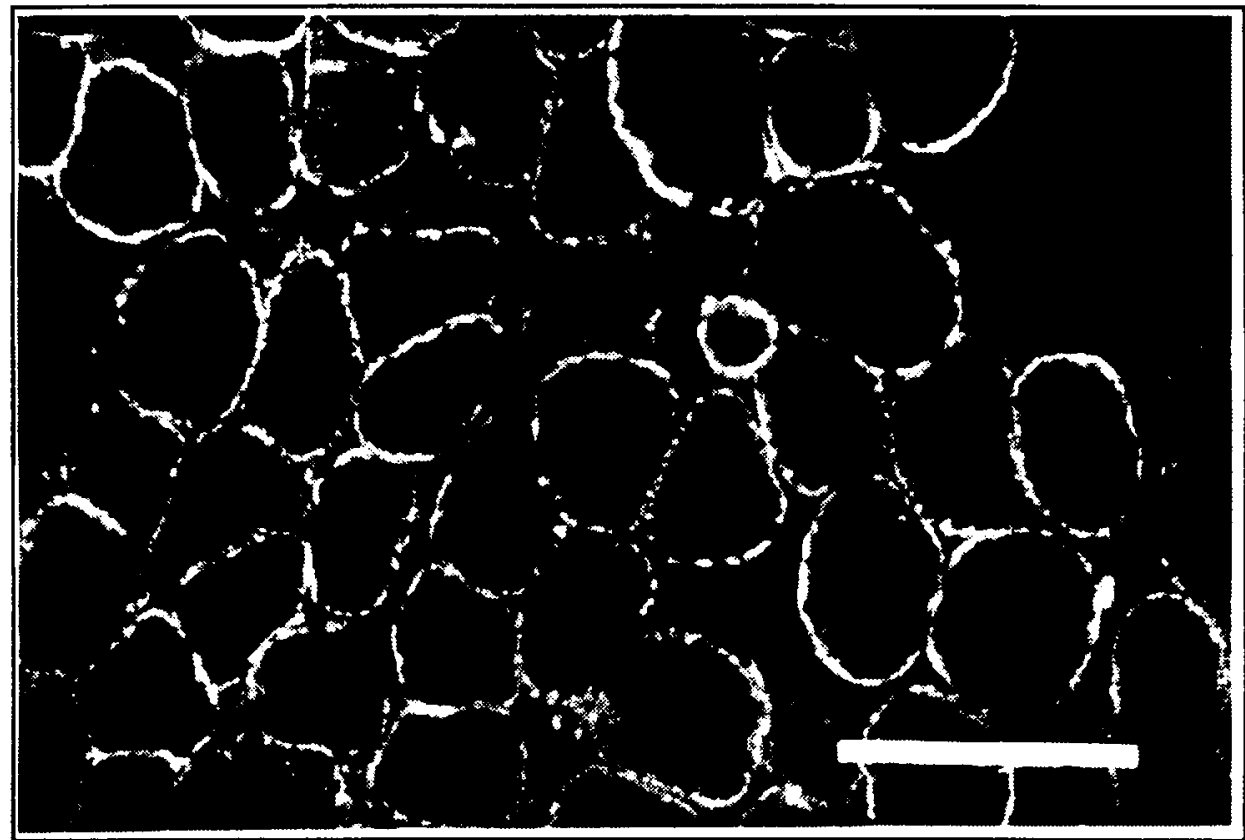

Fig 1. Dystrophin immunostaining. Most of the fibers with gaps at regular intervals, giving an appearance of rosary. Barr $50 \mu$. 


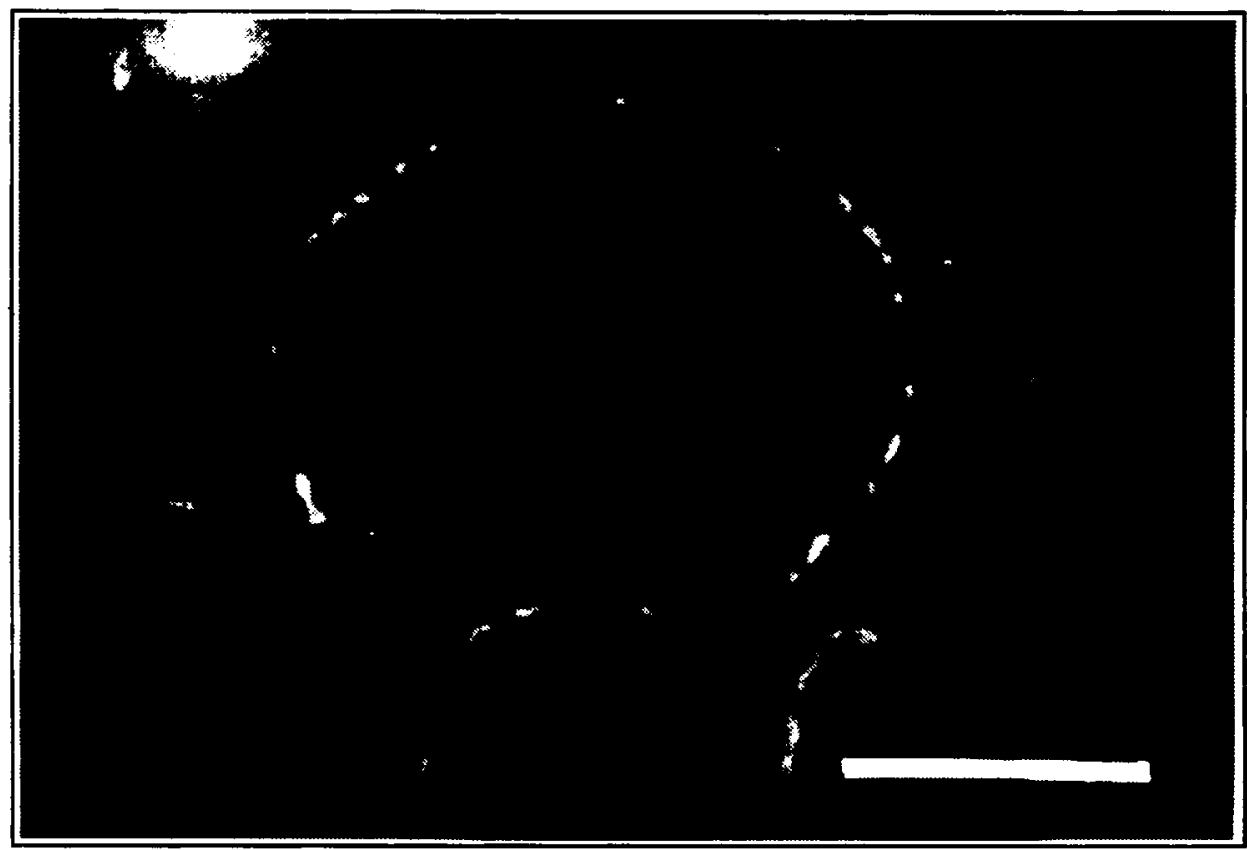

Fig 2. Dystrophin immunostaining. Close up of one fiber with a rosary appearance, with large and small interruptions. Barr $12.5 \mu$.

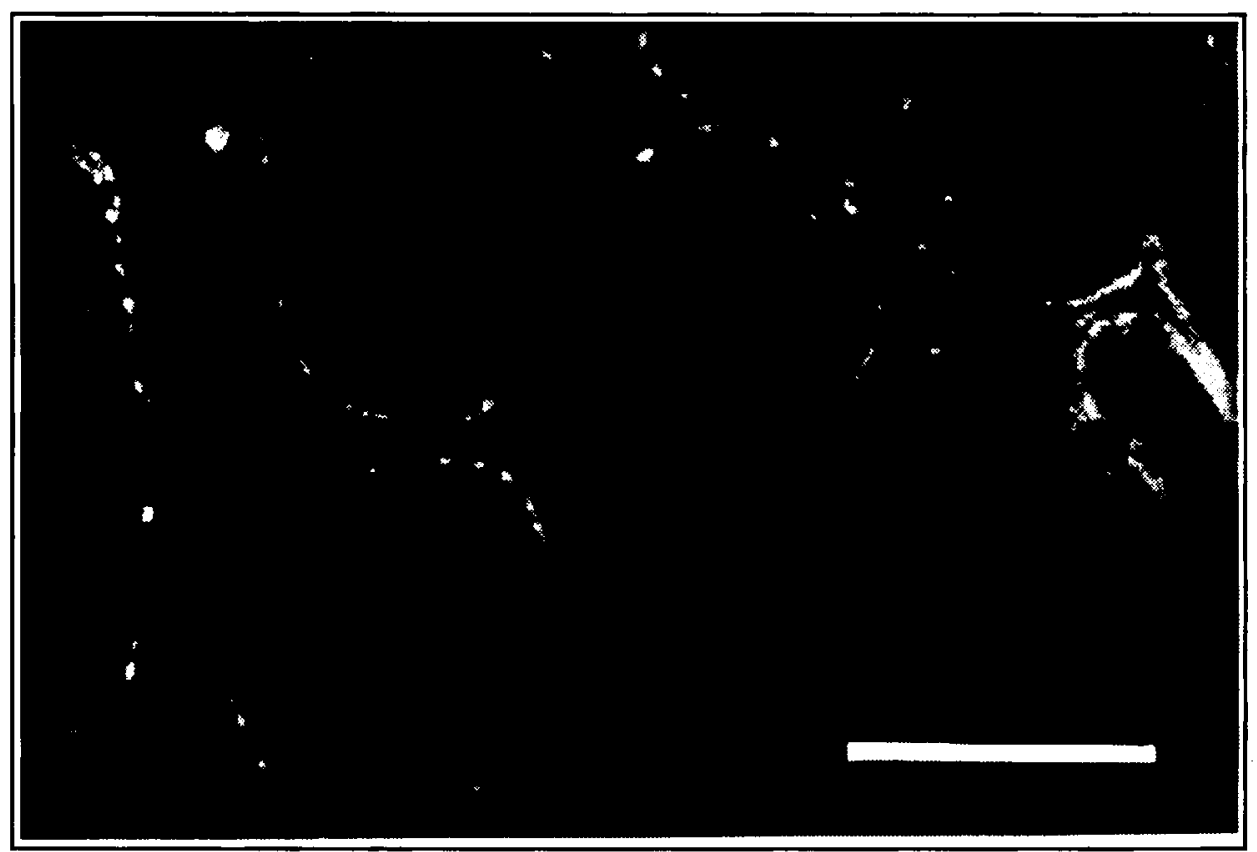

Fig 3. Dystrophin immunostaining. Fibers with large and small interruptions, fibers with minimal dystrophin staining (almost absent). Barr $12.5 \mu$. 
contractures during the disease course (Type 1) ${ }^{3.16 .21}$. Some had involvement of the central nervous system due to a defect in the migration of the neurons during their development, resulting in polymicrogyria and lisencephaly (Type 2 or Fukuyama type) ${ }^{8,18}$. In this study, the case number 13 was type 2 (Fukuyama) and the remaining, type 1 congenital muscular dystrophy.

The serum enzymes may be elevated and the electromyography usually suggests primary muscle involvement (myopathic pattern) ${ }^{8,16,21}$. The muscle biopsies show severe proliferation of the connective tissue, a variable degree of fatty infiltration, and a moderate variation of fiber size within the fascicles, with small and large diameter fibers. A variable degree of necrosis, phagocytosis and regeneration is found according to age. It was observed an involvement of all fiber types, a predominance of type 1 , a decrease of type $2 \mathrm{~B}$ fibers and an increased number of type $2 \mathrm{C}$ fibers as the disease progressed $3,8,16,18,21$.

Both types of congenital muscular dystrophy have an autosomal recessive trait being both sexes equally involved, but type 1 sometimes appears sporadically ${ }^{3,8.21}$. For type 2 (Fukuyama) the gene frequency is 5.2-9.7 $\times 10^{-3}$, suggesting a carrier rate population of one out of 52-97 persons and an incidence of the disease in the population of 6.9-11.9 per 100,000 people . There is also a report of a family with congenital muscular dystrophy that has a relative with Duchenne muscular dystrophy $1 "$ and a case of a 7 year-old girl who had small scattered groups of muscle fibers in the muscle biopsy with no dystrophin staining or with reduced and patched dystrophin staining similar to the cases described in this paper ${ }^{1}$.

Due to the similarities between the histopathological changes of the congenital muscular dystrophies and early Duchenne muscular dystrophy, some studies undertook dystrophin analyses. Two papers reported absence of dystrophin in a few cases of the Fukuyama type congenital muscular dystrophy ${ }^{1,4}$. In another paper which studied 51 cases of congenital muscular dystrophies it was found that, in 36 cases of the Fukuyama type, there were occasional fibers with abnormal reaction which seemed confined to early degenerating or regenerating muscle fibers. Also in two patients there was total absence of dystrophin ${ }^{2}$. The total absence of dystrophin in some fibers ( 5 cases) may be due to fiber necrosis. The procedure to differentiate the real absence from the disappearance due to fiber necrosis is by staining for $\beta$-spectrin.

Possible explanations presented for the abnormal dystrophin in the Fukuyama congenital dystrophy cases are: a) mutation of the dystrophin gene results in more severe clinical presentation than the usual Duchenne cases; b) dystrophin deficiency associated to disorders unrelated to Duchenne dystrophy; c) a combination of Duchenne dystrophy and brain damage of unknown etiology with multiple genetic abnormalities involving the dystrophin gene or a possible interaction of both genes ${ }^{1,4}$.

A report, which studied 28 patients with congenital muscular dystrophy, found abnormalities in the dystrophin distribution in 3 cases only, and suggested that the Duchenne muscular dystrophy gene has a wide variety of expressions. Some cases have very mild and others very severe phenotype, not commonly present at birth or even during the first year of life. At one end of the spectrum, the more severe is the congenital muscular dystrophy and at the other, mild, is the Becker muscular dystrophy ${ }^{17}$. Moreover, the repart of a boy with a congenital myopathy, absence of dystrophin and deletion at the 5 'end of the dystrophin gene, seems to corroborate to this hypothesis ${ }^{20}$. Also, most of our cases had the dystrophin immunofluorescence appearance similar to that one of the cases in a paper which reported the variability in carriers of Duchenne and Becker muscular dystrophy ${ }^{7}$.

The report of the dystrophin-associated transmembrane glycoprotein (DAP), its severe reduction in the sarcolemma of Duchenne muscular dystrophy and the absence of the $50 \mathrm{KDa}$ DAP in childhood autosomal recessive muscular dystrophy raised some questions as to if they are also abnormal in congenital muscle dystrophies ${ }^{12,19}$. Recently a reduced expression of the $43 \mathrm{KDa}$ in the Fukuyama type of congenital muscular dystrophy with near normal expression of dystrophin was reported ${ }^{13.15}$. This suggested an interaction between the dystrophin and the gene of the Fukuyama 
type of dystrophy, with the possibility of the $43 \mathrm{KDa}$ dystroglycan gene as a possible candidate for mutation ${ }^{13,15}$.

The present study suggests an abnormal expression of the dystrophin by immunoflorescence in this group of patients. It might have a similar or near-by genetic locus abnormality for dystrophin production. Also, the different types of antibodies used in other papers and the different thickness of the sections during the immunocytochemical preparation may explain the discrepancies in the incidence of the abnormalities reported. This study raises some questions upon the specificity of the immunofluorescence test of dystrophin alone in cases of children with early Becker muscular dystrophy due to the similarity of the abnormalities within the congenital muscular dystrophies. It also points to an abnormality of the dystrophin distribution in the sarcolemma in some cases of congenital muscular dystrophies. With the absence of the rosary dystrophin appearence it would not be possible for us to tell whether some of our cases are early Becker or childhood autosomal recessive muscular dystrophy. Further studies on immunobloting of the dystrophin as well as on the dystrophinglycoprotein complex are necessary in order to better elucidate congenital muscular dystrophy pathogenesis

Acknowledgments - The authors are grateful to Miss Sumico Nakagawa for the technical assistance and Miss Susana Castilho for the manuscript review.

\section{REFERENCES}

1. Arahata L, Hoffman EP, Kunkel LM et al. Dystrophin diagnosis: comparison of dystrophin abnormalities by immunofluorescence and immunoblot analyses. Proc Nat Acad Sci USA 1989, 86:7154-7158.

2. Arikawa E, Arahata K, Nonaka I, Sugita H. Dystrophin analysis in congenital muscular dystrophy. Neurology 1990, 40 (Suppl):206.

3. Banker BQ. Congenital muscular dystrophy. In: Engel AG, Banker BQ (eds). Myology: basic and clinical. New York: McGraw-Hill, 1986.

4. Beggs AH, Neuman PE, Arahata $\mathrm{K}$ et al. Possible influences on the expression of $\mathrm{X}$ chromosome-linked dystrophin abnormalities by heterozygosity for autosomal recessive Fukuyama congenital muscular dystrophy. Proc Nat Acad Sci USA 1992, 89:623-627.

5. Bonilla E, Samitt CE, Miranda AF et al. Duchenne muscular dystrophy: deficiency of dystrophin at the muscle cell surface. Cell 1988, 54:447-452.

6. Bonilla E, Schmidt B, Samitt CE et al. Normal and dystrophin-deficient muscle fibers in carriers of the gene for Duchenne muscular dystrophy. Am J Pathol 1988, 133:440-445.

7. Bushby KMD, Goodship JA, Nicholson LVB et al. Variability in clinical, genetic and protein abnormalities in manifesting carriers of Duchenne and Becker muscular dystrophy. Neuromusc Disord 1993, 3:57-64.

8. Fukuyana Y, Osawa M, Suzuki H. Congenital progressive muscular dystrophy of the Fukuyma type: clinical, genetic and pathological considerations. Brain \& Develop 1981, 3:2-29.

9. Hoffman EP, Brown RH Jr, Kunkel LM. Dystrophin: the protein product of the Duchenne muscular dystrophy locus. Cell 1987, 51:919-928.

10. Hoffman EP, Hudecki MS, Rosemberg PA, Pollina CM, Kunkell LM. Cell and fiber-type distribution of dystrophin. Neuron 1988, 1:411-420.

11. Iannaccone ST, Bove K, Towbin R, Ford LM, Keelber P. Congenital muscular dystrophy. Neurology 1988, 38 (Suppl): 187.

12. Matsumura K, Campbel] KP. Deficiency of dystrophin-associated proteins: a common mechanism leading to muscle cell necrosis in severe childhood muscular dystrophies. Neuromusc Disord 1993, 3:109-118.

13. Matsumura K, Campbell HP. Dystrophin-glycoprotein complex: its role in the molecular pathogenesis of muscular dystrophy. Muscle \& Nerve 1994, 17:2-15.

14. Matsumura K, Nonaka I, Arahata K, Campbell KP. Partial deficiency of dystrophin-associated protein in a young girl with sporadic myopathy and normal karyotype. Neurology 1993, 43:1267-1268.

15. Matsumura K, Nonaka, I., Campbell KP. Abnormal expression of dystrophin-associated proteins in Fukuyama-type congenital muscular dystrophy. Lancet 1993, 341:521-522.

16. McMenamin JB, Becker LE, Murphy EG. Congenital muscular dystrophy: a clinicopathological report of 24 cases. J Pediatr 1982, 100:692-697. 
17. Mendel JR, lannaccone ST, Burrow KL et al. Dystrophin analysis in congenital muscular dystrophy. Ann Neurol 1990, 28:270.

18. Nonaka I, Sugita H, Takada K, Kumagai K. Muscle histochemistry in congenital muscular dystrophy with central nervous system involvment. Muscle \& Nerve 1982, 6:102-106.

19. Ohlencieck K, Matsumura K, Ionasescu VV et al. Duchenne muscular dystrophy: Deficiency of dystrophinassociated proteins in the sarcolemma. Neurology 1993, 43:795-800.

20. Prelle A, Moggio M, Bonilla E et al. Dystrophin deficiency in a congenital myopathy. Neurology 1990 , 40(Suppl):207.

21. Serratrice G, Cros D, Pellisier JL, Gastaut JL, Pouget J. Dystrophie musculaire congénitale. Rev Neurol 1980,136:445-472.

22. Wemeck LC. The value of muscle biopsy in Neurology: a study of 290 biopsies. Rev Bras Clin Terap 1981, 10(Supl): 2-24.

23. Werneck LC, Bonilla E. Dystrophin in the differentiation between Duchenne and Becker muscular dystrophies: an immunofluorescence study of dystrophin in muscle biopsy related with the clinical stage, serum enzymes and histological findings. Arq Neuropsiquiatr 1990, 48:454-464. 